\title{
Tobacco control education, attitudes and beliefs of Nigerian health profession students
}

\author{
Oluwatunmise Awojobi ${ }^{1}$, Ray Croucher ${ }^{2}$ \\ ${ }^{1}$ Unit of Social and Behavioural Sciences, Dental Institute, King's College London, UK \\ ${ }^{2}$ Centre for Clinical and Diagnostic Oral Sciences, Barts and The London School of Medicine and Dentistry, Queen Mary \\ University of London, UK
}

Correspondence: Oluwatunmise Awojobi, Unit of Social and Behavioural Sciences, Dental Institute, King's College London, Caldecot Road, London SE5 9RW. Email: tunmise.awojobi@kcl.ac.uk

Accepted: August 10, 2012

\begin{abstract}
Objectives: The purpose of this study is to explore tobacco control-related education of health profession students and demonstrate variations according to course of study. Methods: This was a cross-sectional survey of 154 of third year nursing, pharmacy, medical and dental students in a tertiary institution in Lagos, Nigeria. The validated Global Health Professional Students survey questionnaire was used to collect data on recall of tobacco-related training, attitudes to tobacco control and beliefs about the role of health professionals in tobacco control. This was voluntary and anonymous. Descriptive and univariate analysis were conducted.
\end{abstract}

Results: Only $11.8 \%(\mathrm{n}=18)$ of all respondents recalled being trained on all possible items of formal tobacco-related training. Pharmacy students had significantly low levels of training recall $\left(\chi 2_{(3)}=9.88 ; \mathrm{p}=0.02\right)$. Nursing students were reported to have the most positive attitudes to tobacco control with the highest mean score of 4.27 (95\%CI= 3.884.66). However, there was no significant difference in attitudes to tobacco control. Compared to other students, Nursing students were significantly less likely to believe that as health professionals they had a role in tobacco-control $\left(\chi 2_{(3)}=8.06 ; \mathrm{p}=0.045\right)$.

Conclusions: Many respondents believed they have a role in providing cessation interventions and that specific training should be part of the education they receive. However, fewer respondents report receiving such training. The education and training of these samples of health profession students needs to place more emphasis on their role in tobacco control if they are to effectively function as health promoting health professionals in preventing tobacco-related diseases.

Keywords: Tobacco use cessation, tobacco control, cessation counselling, health profession students, training

\section{Introduction}

Tobacco is the second major cause of death in the world. It is currently responsible for about 5 million deaths each year. ${ }^{1}$ It is also inextricably linked with poverty. In some non-established market economies, the poorest households have been reported to spend as much as $10 \%$ of total household expenditure on tobacco. ${ }^{2}$

In Nigeria, a national survey in 1990 reported current smoking prevalence amongst adults as $8.9 \%{ }^{3}$ compared to a worldwide average of 30.2\%. ${ }^{4}$ The 2001 Global Youth Tobacco Survey (GYTS) in Nigeria reported a higher prevalence of current tobacco use amongst Nigerian youths aged $13-15$ years, ranging from $18.1 \%$ to $22.1 \%{ }^{3}$ (compared with a worldwide average of about $18.7 \%{ }^{5}$ ). This suggests a future increase in smoking prevalence amongst Nigerian adults and therefore a need to ensure health profession students' training is designed to prepare them to deliver effective interventions as health professionals in order to deal with the possible effect of this trend.

As part of guidelines for smoking cessation released in 1999 for the English national healthcare system, based on evidence, it was recommended that smoking and smoking cessation be part of the core curriculum and basic training of all health professionals. ${ }^{6}$ Training and retraining of health workers was also recognized as an integral component of the health sector development at the Nigerian National Health Conference. ${ }^{7}$ 
Indeed, the World Health Organization (WHO) expects physicians, nurses, dentists and pharmacists and all health professionals to address tobacco dependence as part of their standard care practice in the everyday health-care setting. ${ }^{8}$ Teaching about tobacco in medical schools can provide students with adequate grounding in evidencebased strategies for when they enter medical practice. ${ }^{9}$ Reviews of smoking cessation interventions carried out by different categories of health professionals ${ }^{10-13}$ in various healthcare settings ${ }^{14-15}$ have established the effectiveness of several interventions. For instance, brief advice, as summarised by the five "As", has been shown to be effective in helping smokers to quit. ${ }^{16-17}$ Healthcare professionals who receive cessation training are more likely to perform smoking cessation tasks than untrained controls and more so when prompts and reminders are used. Additionally, training health professionals in smoking cessation increased the number of smokers identified and offers of advice and support for quitting. ${ }^{18}$

The Global Health Professional Survey (GHPS) is part of the Global Tobacco Surveillance System (GTSS), which collects data through three surveys: the Global Youth Tobacco Survey (GYTS), the Global School Personnel Survey (GSPS) and GHPS. GHPS collects data on tobacco use amongst healthcare professional students and the presence of self-reported smoking cessation and tobacco control training in the curriculum.

Findings from the GHPS pilot study show that current cigarette smoking (daily or occasionally) among health professional students was higher than $20 \%$ in seven of the 10 countries surveyed with variation by country and health profession studied. ${ }^{19}$ In a separate Chinese study, the proportion of the study sample who currently smoke was reported as $4 \%$ and the proportion who had ever smoked was reported as $55 \%$ in dental students. ${ }^{20}$ In both of these studies, nearly all respondents believed they should receive specific training in cessation techniques. However, the proportion of students who reported receiving such training was much lower.

European and American studies have also explored the presence of tobacco use cessation and counselling in the curriculum of health profession training schools. ${ }^{21-23}$

The literature relating to this research field for nonestablished market economies in general, and specifically for Nigeria, is limited. One study conducted in Nigeria ${ }^{24}$ found that $89.2 \%$ of dental students positively identified tobacco use as an aetiological factor for oral cancer but only $38.5 \%$ provided routine advice to patients on alcohol and tobacco use cessation. The study highlighted the need for a more structured teaching program including the training of students in preventive activities and also smoking cessation counselling.

This training need is even more vital because Nurses and Midwives outnumber physicians by a ratio of $6: 1$ in Nigeria. ${ }^{25}$ Members of the public are more likely to come into contact with this group, than with any other healthcare professionals. However, an Italian study reported nursing students as less aware of their role in smoking cessation than their medical counterparts. ${ }^{26}$

As Nigeria was not part of the GHPS pilot Study conducted by the WHO in 2005, there are no findings on tobacco use amongst healthcare profession students and the presence of self-reported tobacco-related training in the curriculum of Nigerian health profession students that are comparable.

This paucity of information regarding comparable data from less developed countries (which are likely to face different challenges to counterparts in developed countries) calls for action. Many of the findings relating to tobacco use and cessation counselling education were conducted in developed countries and those conducted in less developed countries tend to look at students of one health specialty group. Furthermore, available data mostly relates only to medical students and other non-medical university students. No data on Nursing, Pharmacy or Dental Students exist despite there being evidence to suggest effective interventions can be administered by these groups as well along with medical professionals.

There remains a need for exploration of findings from these studies of health profession students within a nonestablished market economy. The aim of this study was to explore tobacco use and tobacco control-related training of health profession students and demonstrate variations according to course of study in a non-established market economy, specifically, to explore and compare the knowledge, attitude and behaviour of samples of medical, dental, nursing and pharmacy students in relation to tobacco use and tobacco control.

\section{Methods}

\section{Study design and setting}

This cross sectional descriptive study was carried out at College of Medicine, University of Lagos, Nigeria, a federal university. It is one of only four colleges in Nigeria where medical, dental, nursing and pharmacy students are trained concurrently. All training in this College is undertaken in English language. It is a 'smoke-free' environment. ${ }^{1}$

\section{Participants}

The study population was made up of third year students as is required by the WHO for GHPS studies in order to standardize them. As a result of the relatively small number of students in each health specialty and ease of accessibility the aim was to collect a census of the whole population of nursing, pharmacy, dental and medical students.

\section{Study instrument}

The study instrument was based on the validated GHPS questionnaire. ${ }^{19}$ The GHPS questionnaire was developed by the WHO, Centres for Disease Control (CDC) and 
prevention and Canadian Public Health Association (CPHA) in order to collect data on tobacco use and cessation counselling among health professional students in their third year of study in all WHO member states. It was selfadministered and completed anonymously; it consisted of 42 close-ended questions. Data was collected on several areas of interest including the presence of tobacco-related curriculum in their training programs (e.g. recall of formal training in smoking cessation approaches), their beliefs about their role in tobacco control, knowledge and attitudes towards tobacco control (e.g. support for complete ban of smoking in enclosed public places) and the proportion of the sample that use tobacco along with demographics. The use of this GHPS questionnaire would allow comparison with other studies conducted elsewhere.

\section{Data collection}

Contact was made with the class or group representatives of the third year students who were informed about the study and its purpose. Instructions were given and the exact number of questionnaires required for each class or group was handed over to the representatives. Questionnaires were distributed at the end of lectures and all the students that were present completed the questionnaires. Data was collected between July and August 2007.

\section{Data analysis}

Data was entered into Microsoft Excel and analysed using Statistical Package for Social Sciences (SPSS). Frequency distributions were computed for all categories. Relationships and associations between variables like programme of study, tobacco use, recall of formal training, attitudes and beliefs were tested using Chi-square tests. Total scores for the main outcomes of interest (attitudes to tobacco control, beliefs about the role of health professionals and recall of formal training) were computed. Tests of normality showed scores were not normally distributed therefore the nonparametric Kruskal-Wallis test was used to assess differences in recall of training, attitudes to tobacco control and beliefs about the role of health professionals according to health profession course being studied. Where statistical significance was achieved, further post-hoc tests were carried out to identify which groups were statistically significantly different from one another. The level of significance adopted was 0.05 .

\section{Ethical considerations}

Ethical approval was sought and received from Queen Mary University of London research ethics committee as they were the study sponsors. The College of Medicine, University of Lagos does not have a health research ethics committee which is registered with the national health research ethics committee in Nigeria (the national body in charge of registering and auditing health research ethics committees). The study purpose was explained to students who were assured their participation was voluntary, that they could withdraw at any time and that individual data would be anonymized. Formal permission for the survey was provided by the dean of basic clinical sciences who is in charge of third year students. The support of the class representatives was sought in the distribution of the questionnaires.

\section{Results}

There were 154 respondents out of the 214 third year health profession students. This represents an overall response rate of $72 \%$ including $100 \%$ of dental and pharmacy, $52 \%$ of medical and $92 \%$ of nursing students. Fifty eight percent were male students with almost half (41.6\%) of respondents aged 22-25 years. Nursing students were more likely female (73.1\%) whereas pharmacy students were more likely male $(81.1 \%)\left(\chi_{(3)}=18.447 ; \mathrm{p}=0.000\right)$.

Overall, the proportion of respondents that reported that they currently smoke was $4.5 \%$ (during the preceding 30 days before completing the questionnaire) and the proportion that reported ever smoking was $31.2 \%$. Table 1 shows the variation in the proportions of current and ever smokers by gender and course. This variation in tobacco use was not found to be statistically significant.

Individual items relating to recall of tobacco-related training and attitude to tobacco control are presented in Table 2.

Table 1. Smoking Status of health profession students in this study according to course and gender $(\mathrm{N}=154)$

\begin{tabular}{lcc}
\hline Variable & $\begin{array}{c}\text { Current smoker } \\
(\%)\end{array}$ & $\begin{array}{c}\text { Ever smoker } \\
(\%)\end{array}$ \\
\hline Course & & \\
$\quad$ Nursing & 3.8 & 23.1 \\
Pharmacy & 5.4 & 32.4 \\
Dentistry & 3.4 & 27.6 \\
$\quad$ Medicine & 4.8 & 35.5 \\
Gender & & \\
Male & 6.7 & 42.2 \\
Female & 1.6 & 15.6 \\
\hline
\end{tabular}

\section{Recall of tobacco related training}

There were seven items in total for which training recall was reported (Table 2). The overall mean value for recall was found to be 4.63 items (95\% CI=4.37-4.89) with both the median and mode being 5 . Five of the seven items were reported by $23.7 \%$ of respondents. Only $11.8 \%$ of all respondents recalled being trained on all possible items of formal tobacco-related training and four respondents did not recall any of the seven training items. The highest level of recall was $90.8 \%(n=139)$ for being taught about the dangers of smoking, followed by $87.6 \%(n=134)$ for learning the importance of taking tobacco history and $80.4 \%(n=123)$ for having heard of Nicotine Replacement Therapy (NRT). The lowest level of recall was for being taught smoking cessation techniques with which to aid patients who want to 
quit at only $34.6 \%(n=53)$. Nursing students were more likely to have discussed reasons for smoking $(\mathrm{p}=0.006)$ and the importance of providing educational materials $(\mathrm{p}=0.019)$, whilst dental students were more likely to have heard of Nicotine Replacement Therapy $(\mathrm{p}=0.000)$.

Table 2. Proportions of respondents who recall individual items of tobacco-related training and show positive attitudes to individual items of tobacco control according to course $(\mathrm{N}=154)$

\begin{tabular}{|c|c|c|c|c|c|}
\hline $\begin{array}{l}\text { Health profession } \\
\text { courses }\end{array}$ & $\begin{array}{l}\text { Nursing } \\
\mathrm{N}=26 \\
(\%)\end{array}$ & $\begin{array}{c}\text { Pharmacy } \\
\mathrm{N}=37 \\
(\%)\end{array}$ & $\begin{array}{c}\text { Medicine } \\
\mathrm{N}=62 \\
(\%)\end{array}$ & $\begin{array}{l}\text { Dentistry } \\
\mathrm{N}=29 \\
(\%)\end{array}$ & $\begin{array}{c}\text { Overall } \\
\mathrm{N}=154 \\
(\%)\end{array}$ \\
\hline \multicolumn{6}{|c|}{ Items showing tobacco-related training recall } \\
\hline $\begin{array}{l}\text { Taught dangers of } \\
\text { smoking }\end{array}$ & $\begin{array}{c}26 \\
(100)\end{array}$ & $\begin{array}{l}26 \\
(72)\end{array}$ & $\begin{array}{l}59 \\
(95)\end{array}$ & $\begin{array}{l}28 \\
(97)\end{array}$ & $\begin{array}{l}139 \\
(91)\end{array}$ \\
\hline $\begin{array}{l}\text { Discussed reasons } \\
\text { why people smoke }\end{array}$ & $\begin{array}{c}22 \\
(85)\end{array}$ & $\begin{array}{l}21 \\
(58)\end{array}$ & $\begin{array}{l}35 \\
(57)\end{array}$ & $\begin{array}{c}11 \\
(38)\end{array}$ & $\begin{array}{l}89 \\
(58)\end{array}$ \\
\hline $\begin{array}{l}\text { Learn the importance } \\
\text { of taking tobacco use } \\
\text { history }\end{array}$ & $\begin{array}{c}26 \\
(100)\end{array}$ & $\begin{array}{l}20 \\
(54)\end{array}$ & $\begin{array}{c}59 \\
(97)\end{array}$ & $\begin{array}{c}29 \\
(100)\end{array}$ & $\begin{array}{l}134 \\
(88)\end{array}$ \\
\hline $\begin{array}{l}\text { Received training in } \\
\text { smoking cessation } \\
\text { techniques }\end{array}$ & $\begin{array}{c}12 \\
(46)\end{array}$ & $\begin{array}{c}11 \\
(30)\end{array}$ & $\begin{array}{c}21 \\
(34)\end{array}$ & $\begin{array}{c}9 \\
(31)\end{array}$ & $\begin{array}{l}53 \\
(35)\end{array}$ \\
\hline $\begin{array}{l}\text { Importance of provid- } \\
\text { ing educational } \\
\text { materials }^{\ddagger}\end{array}$ & $\begin{array}{c}21 \\
(81)\end{array}$ & $\begin{array}{c}19 \\
(51)\end{array}$ & $\begin{array}{l}48 \\
(79)\end{array}$ & $\begin{array}{l}21 \\
(72)\end{array}$ & $\begin{array}{l}109 \\
(71)\end{array}$ \\
\hline $\begin{array}{l}\text { Heard of nicotine } \\
\text { replacement } \\
\text { therapy }\end{array}$ & $\begin{array}{c}12 \\
(46)\end{array}$ & $\begin{array}{l}27 \\
(73)\end{array}$ & $\begin{array}{l}55 \\
(90)\end{array}$ & $\begin{array}{c}29 \\
(100)\end{array}$ & $\begin{array}{l}123 \\
(80)\end{array}$ \\
\hline $\begin{array}{l}\text { Heard of the use of } \\
\text { antidepressants }\end{array}$ & $\begin{array}{l}15 \\
(58)\end{array}$ & $\begin{array}{l}15 \\
(41)\end{array}$ & $\begin{array}{c}22 \\
(36)\end{array}$ & $\begin{array}{c}11 \\
(38)\end{array}$ & $\begin{array}{l}63 \\
(41)\end{array}$ \\
\hline \multicolumn{6}{|c|}{ Items showing attitudes to tobacco control } \\
\hline $\begin{array}{l}\text { Ban sales of tobacco } \\
\text { products to } \\
\text { adolescents }\end{array}$ & $\begin{array}{c}24 \\
(92)\end{array}$ & $\begin{array}{c}35 \\
(95)\end{array}$ & $\begin{array}{l}54 \\
(89)\end{array}$ & $\begin{array}{c}28 \\
(100)\end{array}$ & $\begin{array}{l}141 \\
(93)\end{array}$ \\
\hline $\begin{array}{l}\text { Complete ban of } \\
\text { tobacco advertise- } \\
\text { ments }\end{array}$ & $\begin{array}{c}21 \\
(81)\end{array}$ & $\begin{array}{l}24 \\
(65)\end{array}$ & $\begin{array}{c}39 \\
(64)\end{array}$ & $\begin{array}{c}14 \\
(50)\end{array}$ & $\begin{array}{c}98 \\
(65)\end{array}$ \\
\hline $\begin{array}{l}\text { Ban smoking in } \\
\text { restaurants }\end{array}$ & $\begin{array}{l}23 \\
(89)\end{array}$ & $\begin{array}{l}29 \\
(85)\end{array}$ & $\begin{array}{l}54 \\
(87)\end{array}$ & $\begin{array}{l}27 \\
(93)\end{array}$ & $\begin{array}{l}133 \\
(88)\end{array}$ \\
\hline $\begin{array}{l}\text { Ban smoking in } \\
\text { discos, pubs and } \\
\text { bars }\end{array}$ & $\begin{array}{c}18 \\
(69)\end{array}$ & $\begin{array}{c}17 \\
(50)\end{array}$ & $\begin{array}{c}24 \\
(39)\end{array}$ & $\begin{array}{c}12 \\
(41)\end{array}$ & $\begin{array}{c}71 \\
(47)\end{array}$ \\
\hline $\begin{array}{l}\text { Ban smoking in all } \\
\text { enclosed public } \\
\text { places }^{\dagger}\end{array}$ & $\begin{array}{l}25 \\
(96)\end{array}$ & $\begin{array}{l}26 \\
(77)\end{array}$ & $\begin{array}{l}56 \\
(90)\end{array}$ & $\begin{array}{l}28 \\
(97)\end{array}$ & $\begin{array}{l}135 \\
(89)\end{array}$ \\
\hline
\end{tabular}

"Proportions and totals may vary as a result of missing data from question to question; ${ }^{\dagger} p<0.01 ;{ }^{\ddagger} p<0.05$.

\section{Attitude to tobacco control}

Attitudes of the health profession students to five tobacco control strategies are also shown in Table 2. These strategies range from banning sales to adolescents to banning of smoking in all enclosed public spaces. Forty point five percent of all respondents $(n=62)$ were in support of all five items indicating positive attitudes to tobacco control while $2 \%$ did not support any of the tobacco control strategies. The highest level of support (92.8\%) was for the banning of sales of tobacco products to adolescents and lowest level of support (47.3\%) was for the banning of smoking in discos, pubs and bars. However, the difference in proportions of respondents in each course supporting these individual items was not found to be statistically significant except for one item. Nursing students were more likely to be in support of banning smoking in all enclosed public spaces compared with all other groups $(\mathrm{p}=0.031)$.

162
Beliefs about the role of health professionals in cessation counselling

The individual items representing beliefs of respondents about the role of health professionals in cessation counselling are presented in Table 3. There were eight items in all demonstrating beliefs and possible total scores could be between zero and eight items. Amongst the respondents, $45.9 \%(n=68)$ agreed with all eight items demonstrating positive beliefs about the role of health professionals while $1.4 \%(n=2)$ agreed with none. Overall, $96.7 \%$ of respondents $(\mathrm{n}=146)$ believe that health professionals have a role in giving advice or information about smoking cessation while 94.7\% ( $\mathrm{n}=143)$ agree that health professionals should receive specific cessation training.

Table 3. Proportions of respondents agreeing with each individual items of belief about the role of health professionals in cessation counselling according to course ${ }^{*}(\mathrm{~N}=154)$

\begin{tabular}{|c|c|c|c|c|c|}
\hline $\begin{array}{l}\text { Health profession } \\
\text { courses }\end{array}$ & $\begin{array}{c}\text { Nursing } \\
(\mathrm{N}=26) \\
(\%)\end{array}$ & $\begin{array}{l}\text { Pharmacy } \\
(\mathrm{N}=37) \\
(\%)\end{array}$ & $\begin{array}{c}\text { Medicine } \\
(\mathrm{N}=62) \\
(\%)\end{array}$ & $\begin{array}{l}\text { Dentistry } \\
(\mathrm{N}=29) \\
(\%)\end{array}$ & $\begin{array}{c}\text { Overall } \\
(\mathrm{N}=154) \\
(\%)\end{array}$ \\
\hline \multicolumn{6}{|c|}{ Items showing beliefs about the role of health professionals } \\
\hline $\begin{array}{l}\text { Health profes- } \\
\text { sionals should } \\
\text { have specific } \\
\text { cessation training }\end{array}$ & $\begin{array}{c}25 \\
(96)\end{array}$ & $\begin{array}{c}32 \\
(94)\end{array}$ & $\begin{array}{l}58 \\
(94)\end{array}$ & $\begin{array}{c}28 \\
(97)\end{array}$ & $\begin{array}{l}143 \\
(95)\end{array}$ \\
\hline $\begin{array}{l}\text { Health profes- } \\
\text { sionals should be } \\
\text { role models }\end{array}$ & $\begin{array}{c}15 \\
(58)\end{array}$ & $\begin{array}{c}22 \\
(65)\end{array}$ & $\begin{array}{c}44 \\
(72)\end{array}$ & $\begin{array}{c}25 \\
(86)\end{array}$ & $\begin{array}{l}106 \\
(71)\end{array}$ \\
\hline $\begin{array}{l}\text { Routine advice } \\
\text { helps in quitting } \\
\text { smoking }\end{array}$ & $\begin{array}{c}25 \\
(96)\end{array}$ & $\begin{array}{c}33 \\
(97)\end{array}$ & $\begin{array}{c}58 \\
(94)\end{array}$ & $\begin{array}{c}28 \\
(97)\end{array}$ & $\begin{array}{l}144 \\
(95)\end{array}$ \\
\hline $\begin{array}{l}\text { Routine advice } \\
\text { helps in stopping } \\
\text { use of other } \\
\text { tobacco }\end{array}$ & $\begin{array}{l}25 \\
(96)\end{array}$ & $\begin{array}{c}32 \\
(94)\end{array}$ & $\begin{array}{c}59 \\
(95)\end{array}$ & $\begin{array}{c}28 \\
(97)\end{array}$ & $\begin{array}{l}144 \\
(95)\end{array}$ \\
\hline $\begin{array}{l}\text { Health profes- } \\
\text { sionals have a } \\
\text { role in smoking } \\
\text { cessation }\end{array}$ & $\begin{array}{c}24 \\
(92)\end{array}$ & $\begin{array}{c}32 \\
(94)\end{array}$ & $\begin{array}{c}61 \\
(98)\end{array}$ & $\begin{array}{c}29 \\
(100)\end{array}$ & $\begin{array}{l}146 \\
(97)\end{array}$ \\
\hline $\begin{array}{l}\text { Increased chanc- } \\
\text { es of quitting with } \\
\text { the help of health } \\
\text { professionals }\end{array}$ & $\begin{array}{c}24 \\
(92)\end{array}$ & $\begin{array}{c}30 \\
(88)\end{array}$ & $\begin{array}{l}56 \\
(90)\end{array}$ & $\begin{array}{l}26 \\
(90)\end{array}$ & $\begin{array}{l}136 \\
(90)\end{array}$ \\
\hline $\begin{array}{l}\text { Health profes- } \\
\text { sionals less likely } \\
\text { to give advice } \\
\text { when they smoke }\end{array}$ & $\begin{array}{c}12 \\
(46)\end{array}$ & $\begin{array}{c}24 \\
(67)\end{array}$ & $\begin{array}{c}47 \\
(78)\end{array}$ & $\begin{array}{c}21 \\
(72)\end{array}$ & $\begin{array}{l}104 \\
(69)\end{array}$ \\
\hline $\begin{array}{l}\text { Health profes- } \\
\text { sionals less likely } \\
\text { to give advice } \\
\text { when they use } \\
\text { other tobacco }{ }^{\dagger}\end{array}$ & $\begin{array}{c}11 \\
(42)\end{array}$ & $\begin{array}{c}25 \\
(69)\end{array}$ & $\begin{array}{c}45 \\
(75)\end{array}$ & $\begin{array}{c}20 \\
(69)\end{array}$ & $\begin{array}{l}101 \\
(67)\end{array}$ \\
\hline
\end{tabular}

"Proportions and totals may vary as a result of missing data from question to question; ${ }^{\dagger} \mathrm{p}<0.05$

Proportions of respondents who believe that health professionals should have a role in smoking cessation ranged from $100 \%$ amongst dental students to $92.3 \%$ amongst nursing students. These high proportions were also seen in the belief that health professionals should routinely advise patients to quit, ranging from $96.6 \%$ amongst dental students to $93.5 \%$ amongst medical students. However, only of $57.7 \%$ of nursing students believed that health professionals should be role models for their patients.

A smaller proportion of nursing students agreed that health professionals who smoke or use other tobacco are 
less likely to advise patients to stop tobacco use $(46.2 \%$ and $42.3 \%$ respectively). Medical students were the most likely to agree with these. These differences for both items were found to be statistically significant $(p=0.029)$. The differences between proportions for other items were not found to be statistically significant.

\section{Relationships between outcomes and health profession course of study}

Table 4 reports the mean scores for recall of tobacco-related training, attitudes to tobacco control and beliefs about the role of health professionals as well as results of the 'between group' analysis using the Kruskal-Wallis test.

Table 4. Mean Scores and Kruskal- Wallis test for Recall of Tobacco-related Training, Attitudes to Tobacco Control and Beliefs about the role of health professionals in cessation counselling according to course $(\mathrm{N}=154)$

\begin{tabular}{lccc}
\hline $\begin{array}{l}\text { Health profession } \\
\text { course }\end{array}$ & $\begin{array}{c}\text { Recall of } \\
\text { tobacco-related } \\
\text { training } \\
\text { Mean }(95 \% \mathrm{Cl})\end{array}$ & $\begin{array}{c}\text { Attitudes to } \\
\text { tobacco control } \\
\text { Mean }(95 \% \mathrm{Cl})\end{array}$ & $\begin{array}{c}\text { Beliefs about } \\
\text { role of health } \\
\text { professionals } \\
\text { Mean }(95 \% \mathrm{Cl})\end{array}$ \\
\hline Nursing & $5.15(4.66,5.65)$ & $4.27(3.88,4.66)$ & $6.19(5.57,6.82)$ \\
Pharmacy & $3.75(3.02,4.48)$ & $3.71(3.19,4.23)$ & $6.71(6.13,7.28)$ \\
Medicine & $4.87(4.49,5.25)$ & $3.72(3.39,4.05)$ & $7.00(6.62,7.38)$ \\
Dentistry & $4.76(4.33,5.19)$ & $3.82(3.44,4.20)$ & $7.07(6.62,7.52)$ \\
Total & $4.63(4.37,4.89)$ & $3.83(3.63,4.03)$ & $6.80(6.56,7.05)$ \\
\hline Kruskal-Wallis Test & & & \\
\hline$\chi^{2}$ & 9.88 & 3.96 & 8.06 \\
p value & 0.02 & 0.27 & 0.045 \\
\hline \multicolumn{4}{c}{} \\
\hline
\end{tabular}

Nursing students had the highest mean score for items representing training recall (5.15 items, 95\%CI=4.66-5.65) and also attitudes to tobacco control (4.27 items, 95\%CI= 3.88-4.66) while pharmacy students had the lowest mean scores for both (3.75 items, 95\%CI=3.02-4.48 and 3.71 items, 95\%CI=3.19-4.23), respectively. However, nursing students had the lowest mean score for items showing beliefs about the role of health professionals in cessation counselling (6.19 items, 95\%CI=5.57-6.82) compared with an overall mean score of $6.80 \quad(95 \% \mathrm{CI}=6.56-7.05)$. The highest mean score for beliefs, 7.07 items $(95 \% \mathrm{CI}=6.62$ 7.52), was reported amongst dental students.

The Kruskal-Wallis test revealed a statistically significant difference in recall of training across the four different health profession student groups, $\left(\chi 2_{(3)}=9.88 ; \mathrm{p}=0.02\right)$. The highest mean rank (89.08) was achieved by Nursing students and the lowest (58.01) by pharmacy students. This difference between nursing and pharmacy students recall of training was significant $(\mathrm{p}=0.004)$. There was also a significant difference between medicine students (mean rank = 82.23) and pharmacy $(\mathrm{p}=0.005)$. With regards to attitude to tobacco control, there was no significant difference in attitude towards tobacco control across all the groups although both the highest median score and mean rank were achieved by nursing students ( 5 items and 88.75 respectively).
There was a statistically significant difference in beliefs about the role of health professionals in cessation counselling across the four different health profession student groups, $\left(\chi 2_{(3)}=8.055 ; \mathrm{p}=0.045\right)$. The highest mean rank was achieved by dentistry students (81) with a median score of 8 items while nursing students had the lowest mean rank of 55.62 along with the lowest median score of 6 items. The difference in beliefs about their role between nursing students and dentistry students was statistically significant $(\mathrm{p}=0.024)$. Nursing students were also statistically significantly different $(\mathrm{p}=0.009)$ from medical students (mean rank 80.94 and median of 8 items).

\section{Discussion}

The aim of this study was to explore tobacco use and tobacco control-related training of health profession students and demonstrate variations according to course of study.

This exploratory study into the knowledge, attitude and behaviour of samples of medical, dental, nursing and pharmacy students is the first conducted in Nigeria.

The study confirms data reported elsewhere. Firstly, the proportion of this sample of Nigerian health profession students that report being current smokers is lower than that of the general adult population in Nigeria and this has also been reported by other studies of Nigerian health profession students. ${ }^{27,28}$ This proportion is also lower than seven of the ten countries in the GHPS pilot study ${ }^{19}$ but similar to that reported amongst Chinese dental students. ${ }^{20}$ The WHO suggests that smoking prevalence among health professionals may often be a barrier for their involvement in tobacco control; therefore it is vital to help health professionals to quit the use of tobacco if they are to act as role models in tobacco control. ${ }^{29}$ Although the proportion of current smokers in this sample is relatively low, smokers should still be offered assistance to quit by the school where possible.

Secondly, the results confirm that whilst most students believe they have a role in tobacco control and that they should receive specific training, few recalled receiving this training. Richmond et al found the "main difference between medical schools, were that developed countries were twice as likely to have implemented a specific module on tobacco compared with those in less developed countries (39\% vs. $17 \%$ ), whereas less developed schools were twice as likely to teach about tobacco informally ( $41 \%$ vs. $20 \%$ )". The fact that there is less likely to be a specific module on tobacco within medical schools in less developed countries, which Nigeria is a part of, may explain why recall of tobacco-related training is at the level found in this study.

Nevertheless, similar disparities are reported in other GHPS-based studies in other parts of the world, both developing and less developed. ${ }^{19,20}$ Compared with the other health profession students in this study, nursing students 
were significantly less likely to believe they had a role in cessation counselling. This confirms the findings from the Italian Study ${ }^{26}$ and is similar to findings comparing nursing students to other health professional students in an American-based study ${ }^{30}$ which reported a decreased awareness of their professional responsibility to help smokers quit when compared to other students. This belief may be linked to the traditional role of nurses and the proposition that the environment within which nurses work has been historically shaped by gendered social relationships relegating women to positions of lesser power and status within organizations. ${ }^{31}$ According to Sarna, "nursing's involvement in the delivery of interventions for prevention of tobacco use, for the treatment of tobacco dependence, and for reducing exposure to second-hand smoke has not been an expected nor a traditional part of their role" ${ }^{32}$ This may affect their perceptions regarding their role. Pharmacists, like nurses, are often in contact with individuals and communities more than doctors. Findings from this study suggest that pharmacy students were the least likely to recall receiving any training in smoking cessation techniques. Pharmacy students reported the lowest mean score for recall of formal training, significantly lower than nursing students. They also reported the lowest proportions in four out of seven individual items of curriculum recall. A recent review of training received by pharmacy students and pharmacists concluded there is value in providing training to improve their knowledge and skills in providing tobacco cessation counselling and services. ${ }^{33}$ Significant differences in cessation rates between the users of pharmacies staffed by pharmacists trained in smoking cessation and those not trained were also reported. ${ }^{33}$

Study limitations include the use of self-administered questionnaires enabling respondents to only offer socially acceptable responses. The assurance of confidentiality should, nevertheless, be sufficient to allow for reliable responses. Also, third year students with limited patient contact and training were used in this study. This may affect the judgments made about their training. However, this is the group that is expected to take part in the GHPS ideally. This may be good in that it gives enough time to make necessary corrections in training where possible before the students graduate. Additionally, the response rate for medical students was lower than that for the other groups; therefore direct comparisons between the medical student group and other groups should be viewed with caution. Finally, non-parametric tests were used to test differences between groups in this study and they are known to be "less sensitive than their parametric equivalents and may therefore fail to detect differences between groups that actually exist" ${ }^{34}$ Nevertheless, findings in this study are confirmed by other studies done elsewhere.

\section{Implications for education practice and research}

The findings of this exploratory study have implications for both medical education and for future research.

A lack of sufficient training in cessation counselling for health profession students may hinder health professionals from functioning effectively in their role. This is a missed opportunity and an ineffective use of the regular contact between individuals and the healthcare system. The implementation of a specific module on tobacco including cessation counselling can ensure more focussed training and standardization across courses. It will also help students acquire the necessary skills more readily. It is noted that Richmond et al found less developed countries reported more barriers to implementing such a curriculum. ${ }^{9}$ Nevertheless, approximately $70 \%$ of the estimated 4.9 million deaths per year caused by tobacco will occur in less developed countries ${ }^{35}$, therefore there remains an urgent need to equip health professionals for their health-promoting role. In addition, the introduction of a newly developed Doctor of Pharmacy programme in Nigeria ${ }^{36}$ is expected to enable more patient-oriented care. Incorporating a tobacco-related content into this curriculum may help demonstrate how best to integrate tobacco use cessation training for pharmacy students.

There are several suggestions for including the necessary tobacco-related training into the curricula of health profession students which have been successfully piloted. These include the free to use RX for Change ${ }^{\odot}$ : Clinician-Assisted Tobacco Cessation programme ${ }^{37}$ which is a comprehensive curriculum. There is also the web-based international resource, Treatobacco.net ${ }^{38}$ which has current evidence on supporting patients to quit tobacco use along with prepared slide kits that can be used. These are two of several free resources which can be appropriately tailored to the context and setting where it is required provided there is political will among curriculum developers.

To further this research, the published undergraduate curriculum at this college could be correlated with what students' report in this study. This can help identify the possible gaps between what is in the curriculum and what students receive and highlight if the problem is actually a lack of tobacco-related content in the curriculum or the way it is being taught. Qualitative research might also offer a deeper understanding into reasons behind nursing students' low level of belief about their role in smoking cessation counselling. To summarize findings in this study, samples of Nigerian health professional students have low current tobacco experience. Nursing students were more likely to have high levels of training recall but also more negative beliefs about their role in smoking cessation counselling.

Many respondents believed they have a role in providing cessation interventions and that specific training should 
be given. However, fewer respondents report having received such training. We can conclude that if the role of health professionals for tobacco control is to be harnessed, there is a need to reorient training to focus on prevention as well as treatment. In addition, the need to adopt an effective tobacco-related content in the curriculum and training programme needs, which is adapted to the cultural context of the society and healthcare system, cannot be overemphasised.

\section{Conflict of Interest}

The authors declare that they have no conflict of interest.

\section{References}

1. World Health Organisation. Building blocks for tobacco control: a handbook. Geneva: World Health Organization; 2004.

2. World Health Organisation. WHO report on the global tobacco epidemic: the MPOWER package; 2008 [cited 2008 March 5]; Available from: http://www.who.int/tobacco/mpower/mpower_report_full_2008.pdf. 3. Shafey O, Dolwick S, Guindon GE (eds.). The tobacco control country profiles. Atlanta, GA. American Cancer Society, 2003.

4. Corrao MA, Guindon GE, Cokkinides V, Sharma N. Building the evidence base for global tobacco control. Bulletin of the World Health Organization, 2000a;78(7):884-90.

5. Global Youth Tobacco Survey Collaborative Group. Tobacco use among youth: a cross country comparison tobacco control; 2002 [cited 2008 March 3]; Available from: http://tobaccocontrol.bmj.com/cgi/reprint/11/3/252.

6. Raw M, Mcneill A, West R. Smoking cessation: evidence based recommendations for the healthcare system. Br Med J. 1999;318:182-185.

7. Health Reform Foundation of Nigeria. Proceedings of the 2006 Nigeria National Health Conference. 2007 [cited 2012 May 19]; Available from: http://www.herfon.org/docs/NHC2006_Details_of_Proceedings.pdf.

8. World Health Organisation. The role of health professionals in tobacco control. Geneva: World Health Organization; 2005.

9. Richmond R, Zwar N, Taylor R, Hunnisett J, Hyslop F. Teaching about tobacco in medical schools: a worldwide study. Drug Alcohol Rev. 2009; 28(5):484-97.

10. Lancaster T, Stead L. Physician advice for smoking cessation. Cochrane Database Syst Rev. 2004;4:CD000165.

11. Lancaster T, Stead L, Silagy C, Sowden A. Effectiveness of interventions to help people stop smoking: findings from the Cochrane Library. Br Med J 2000;321:355-358.

12. Carr AB, Ebbert J. Interventions for tobacco cessation in the dental setting. Cochrane Database Syst Rev. 2006;6:CD005084.

13. Rice VH, Stead LF. Nursing interventions for smoking cessation. Cochrane Database of Syst Rev. 2008;1:CD001188.

14. Sinclair HK, Bond CM, Stead LF. Community pharmacy personnel interventions for smoking cessation. Cochrane Database of Syst Rev. 2004;1:CD003698.

15. Rigotti NA, Munafo MR, Stead LF. Interventions for smoking cessation in hospitalised patients. Cochrane Database Syst Rev. 2007;3:CD001837.

16. Whitlock EP, Polen MR, Green CA, Orleans T, Klein J. behavioural counselling interventions in primary care to reduce risky/harmful alcohol use by adults: a summary of the evidence for the United States preventive services task force. Ann Intern Med. 2004;140(7):57-580.

17. Lancaster T, Silagy C, Fowler G. Training Health Professionals in smoking cessation. Cochrane Database Syst Rev. 2000;3:CD000214.
18. Gelskey S. impact of a dental/dental hygiene tobacco-use cessation curriculum on practice. J Dent Educ. 2002; 66 (9):1074-1078.

19. Global Tobacco Surveillance System Collaborative Group. Tobacco use and cessation counselling: global health professionals survey pilot study, 10 countries. Tobacco Control 2006;15(Suppl II):ii31-ii34.

20. Tao S, Pau A, Croucher R. Impact of the curriculum on Chinese dental students' tobacco control attitudes and beliefs: a case study of Harbin, China. Int Dent J. 2008;58:181-186.

21. Roddy E, Rubin P, Britton J. A study of smoking and smoking cessation on the curricula of UK medical schools .Tob Control. 2004;13:74-77.

22. McCartan BE, Shanley DB. Policies and practices of European dental schools in relation to smoking; a ten-year follow-up. Br Dent J. 2005;198: 423-425.

23. Weaver RG, Whittaker L, Valachovic R, Broom A. Tobacco control and prevention effort in dental education. J Dent Educ. 2002;66(3):426-429.

24. Uti O, Fashina A. Oral cancer education in dental schools: knowledge and experience of Nigerian undergraduate students. J Dent Educ. 2006;70(6):676-680.

25. World Health Organisation. World health statistics. World Health Organization, Geneva; 2002 [cited 2008 August 7]; Available from: http://www.who.int/whosis/whostat/EN_WHS08_Full.pdf.

26. Melani AS, Verponziani W, Boccoli E, Trianni GL, Federici A, Amerini $\mathrm{R}$, et al. Tobacco smoking habits, attitudes and beliefs among nurse and medical students in Tuscany. Eur J Epidemiol. 2000;16:607-611.

27. Makanjuola A, Daramola T, Obembe O. Psychoactive substance use among medical students in a Nigerian University. World Psychiatry. 2007; 6(2):112-114.

28. Bolajoko AA, Adebayo TO, Babatunde MO Lawal, Opeoluwa OO. Promoting cessation and a tobacco free future: willingness of pharmacy students at the University of Lagos, Nigeria. Tob Induc Dis. 2009;5:13.

29. World Health Organisation. The role of health professionals in tobacco control. Geneva: World Health Organization;2005.

30. Fried J, Reid B, DeVore L. A comparison of health professions student attitudes regarding tobacco curricula and interventionist roles. J Dent Educ. 2004;68(3):370-377.

31. Malone R. Nursing's involvement in tobacco control: historical perspective and vision for the future. Nurs Res. 2006;55(4S):S51-S57.

32. Sarna L, Bialous SA, Rice VH, Wewers ME. Promoting tobacco dependence treatment in nursing education. Drug Alcohol Rev. 2009; 28(5): 507-516.

33. Williams D.M. Preparing pharmacy students and pharmacists to provide tobacco cessation counselling. Drug and Alcohol Rev. 2009;28(5): 533-540.

34. Pallant J. SPSS survival manual: a step by step guide to data analysis using SPSS for Windows. Berkshire, England: Open University Press; 2007.

35. World Health Organization Tobacco and Health in the Developing World. A background paper for the high level round table on tobacco control and development policy; 2002 [cited 2008 August 7]; Available from:http://ec.europa.eu/health/archive/ph_determinants/life_style/tobacco /documents/who_en.pdf.

36. Erah, $\mathrm{P}$. The changing roles of pharmacists in hospital and community pharmacy practice in Nigeria. Trop J Pharm Res. 2003; 2(2):195-196.

37. The Regents of the University of California. Rx for change: clinicianassisted tobacco cessation. 2004 [cited 2012 May 25]; Available from: http://rxforchange.ucsf.edu/.

38. Society for Research on Nicotine and Tobacco, Society for the Study of Addiction, InterAmerican Heart Foundation and the NHS Centre for Smoking Cessation and Training. Treattobacco.net. 2008 [cited 2012 May 25]; Available from: http://www.treatobacco.net/. 